\title{
Effects of change in primary forest cover on armadillo (Cingulata, Mammalia) burrow use in the Central Amazon
}

\section{Efectos del cambio en la cobertura de bosque primario sobre el uso de las madrigueras por los armadillos (Cingulata, Mammalia) en la Amazonia Central}

\author{
María Clara Arteaga ${ }^{1,3 凶}$ and Eduardo Venticinque ${ }^{1,2}$ \\ ${ }^{1}$ Departmento de Ecologia, Instituto Nacional de Pesquisas da Amazônia (INPA), Ap. Postal 478, CEP 69083-000 Manaus, Brazil \\ ${ }^{2}$ Universidade Federal do Rio Grande do Norte. Centro de Biociências, Departamento de Biologia. Campus Universitário, Lagoa Nova, 59078-900. \\ Natal, Brasil. \\ ${ }^{3}$ Current address: Departamento de Ecología de la Biodiversidad, Instituto de Ecología, Universidad Nacional Autónoma de México, Apartado postal \\ 70-275, 04510 México, D. F. México. \\ \mcarteaga@ecologia.unam.mx;mariaclaraarteaga@yahoo.com
}

\begin{abstract}
Transformation of primary forest to other vegetation types alters the availability and distribution of resources, and thus affects their use by species that inhabit the forest. Although armadillos are important earthmover mammals in the Amazon forest, and their burrows play an important physical and ecological role in the ecosystem, the impact of loss of primary forest cover on these organisms has been poorly understood. In order to evaluate the effects of change in the primary forest cover on burrow use by armadillos, we performed 2 censuses in 33 plots within 12 sites of different vegetation cover characteristics, and recorded burrow density and current use. A total of 109 armadillo burrows were found; the sites with higher percentages of primary forest cover showed a larger number of active burrows, although burrow density and the probability of establishing new burrows remained unaffected by this variable. Our results show that areas with higher quantities of primary forest habitat show more intense use by armadillos, probably due to the permanence time of individuals. These findings suggest that the viability of armadillo populations, as well as the role that these animals play within the ecosystem, may be affected in disturbed areas.
\end{abstract}

Key words: Dasypodidae, Brazil, fragmentation, habitat use, mammals.

\begin{abstract}
Resumen. La transformación del bosque primario a otro tipo de vegetación cambia la disponibilidad y distribución de los recursos, afectando su uso por especies que habitan el bosque. Los armadillos son el principal grupo de mamíferos escavadores del Amazonas y sus madrigueras cumplen un papel físico y ecológico en el ecosistema. Sin embargo, no se conoce el impacto de la pérdida del bosque sobre estos organismos. Con el fin de evaluar el efecto de los cambios en la cobertura de bosque primario sobre el uso de sus madrigueras, realizamos 2 censos en 33 parcelas dentro de 12 localidades con diferentes coberturas vegetales y reportamos la densidad y el estado de uso de las madrigueras. Encontramos 109 madrigueras y observamos un mayor número de éstas activas en áreas con mayor cobertura de bosque primario. Entre tanto, la densidad y la probabilidad de fundar nuevas madrigueras no se vio afectada por el tipo de cobertura forestal. Nuestros resultados indican que áreas con mayor cobertura de bosque primario exhiben un uso más intenso por armadillos, probablemente por una mayor permanencia de los individuos. Esto sugiere que la viabilidad de las poblaciones de armadillos y el papel que desempeñan en el ecosistema, puede verse afectado en áreas con hábitat modificado.
\end{abstract}

Palabras clave: Dasypodidae, Brasil, fragmentación, uso del hábitat, mamíferos.

\section{Introduction}

A major consequence of fragmentation is the reduction in habitat quality caused by the transformation of the original vegetation cover to other vegetation types (Fahrig, 2003). This transformation may affect the permanence

Recibido: 10 octubre 2010; aceptado: 23 junio 2011 time and habitat use patterns of organisms in modified environments and, in turn, implies alterations to the richness and composition of species (O'Dea and Whittaker, 2007; Barragán et al., 2011; Narendra et al., 2011), demography of populations (Holland and Bennett, 2010), genetic structure and diversity (Gibbs, 2001; Dharmarajan et al., 2009), and ecological interactions (Laakkonen et al., 2001; Jorge and Howe, 2009).

Tropical regions have been subject to a substantial 
reduction in forest cover, resulting in modified environmental conditions for the native fauna. For example, habitat loss due to deforestation in southern Mexico has caused the local extinction of large mammals that were important to the dispersal of fruits and seeds of tropical trees (Melo et al., 2010), while the primary forest of the Amazon that has been exposed to deforestation led mainly by the cultivation of soybean and clearance for cattle pastures (Fearnside, 2003). Changes in vegetation cover can affect the habits and behavior of a variety of organisms, but whether such changes in habitat conditions are positive or negative depends on the individual species involved. While some mammal and insectivorous bird species of the understory are vulnerable to forest cover alterations (Bierregaard and Stouffer, 1997; Michalski and Peres, 2007; Jorge, 2008), others have responded positively to such changes (Stouffer and Bierregaard, 1995; Malcolm, 1997; Jorge, 2008). Since habitat loss and degradation are important factors that produce changes in biodiversity, investigation about how such modification affects population dynamics of species is of great importance.

In this study, we examine the effects of forest cover loss on habitat use by the main group of excavating mammals in the Amazonian forest, the armadillos (Cingulata). These are solitary and nocturnal animals with a generalist diet composed mainly of invertebrates (McBee and Baker, 1982). Armadillos use their burrows for a variety of purposes such as shelters from predators, safe places for reproduction, and protection from severe climatic conditions such as heavy rain and extreme temperatures (McDonough and Loughry, 2008). As observed in the burrows of other species (Wesche et al., 2007; Eldridge and Whitford, 2009), armadillo burrows may also increase airflow in the soil and thus modify mineralization rates. Furthermore, these burrows can act as refuges for other vertebrate species and form suitable habitats for invertebrates (Machicote et al., 2004; McDonough and Loughry, 2008). These factors highlight the importance of evaluating how changes in primary forest cover affect armadillo habitat use, since these changes may affect the ecosystem at several levels.

The total number of armadillo burrows present, and the proportion in active use, could provide important information about the activity of these species. Armadillo burrows have previously been used as evidence of habitat use in different ecosystems (McDonough et al., 2000; Abba et al., 2007; Arteaga and Venticinque, 2008). The objective of our study was to evaluate how change in the vegetation cover of a primary forest affects the use of the burrows by armadillos. We expected to find a lower density of burrows, a lower proportion of active burrows, and a lower probability of occurrence of new burrows in areas with a lower proportion of primary forest cover.

\section{Materials and methods}

Study area. The study area is located in the Central Amazon, $\left(2^{\circ} 18^{\prime} 21^{\prime \prime}-2^{\circ} 27^{\prime} 46^{\prime \prime} \mathrm{S}\right.$ and $\left.59^{\circ} 45^{\prime} 33^{\prime \prime}-60^{\circ} 06^{\prime} 44^{\prime \prime} \mathrm{W}\right)$, approximately $80 \mathrm{~km}$ north of Manaus, in Brazil. This region was subject to extensive deforestation producing an area composed of primary continuous forest and patches of 1 to 100 ha, surrounded by secondary vegetation. The primary forest is ombrophil terra-firme with a canopy height of 30 to $37 \mathrm{~m}$ (Pires and Prance, 1985) and emergent trees reaching 45 to $50 \mathrm{~m}$. Tree diversity is high, surpassing $280 \mathrm{species} / \mathrm{ha}$ in some areas (Oliveira and Mori, 1999). Secondary vegetation is dominated by Cecropia sp. and Vismia sp. (Pires and Prance, 1985). Annual rainfall in this area varies from 1900 to $2500 \mathrm{~mm}$, with a dry season from June to October (Gascon and Bierregard, 2001). The study area is part of the Biological Dynamics of Forest Fragments Project (BDFFP) at the National Institute for Amazonian Research/Smithsonian Institution (INPA/SI).

Four armadillo species (Cabassous unicinctus, Dasypus novemcinctus, D. kappleri, and Priodontes maximus) are found in the Central Amazon (Emmons and Feer, 1997) and have previously been recorded in the area of the BDFFP (Timo, 2003). It has been suggested that burrow entrances themselves can offer specific information regarding the identity of the armadillo species (Carter and Encarnação, 1983; Abba et al., 2007). However, a previous study suggested that this method is inaccurate in this region, because burrows of similar dimensions may be built by species of similar size or by individuals of different-sized species, belonging to different age classes that happen to coincide in terms of size (Arteaga and Venticinque, 2010). For this reason, the response of the armadillo community as a whole was evaluated, rather than as individual species. We consider that the approach of using the whole armadillo community is interesting and of value because it allows an understanding of the effect of cover forest change over the community at a landscape scale, and provides a basis for future studies at the species level and at smaller geographic scales.

Survey design. We surveyed 12 sites in a forest landscape that included fragments of different size and sites of continuous forest. We included 4 fragments of 1 ha, 3 fragments of 10 ha, 2 of 100 ha, and 3 sites within areas of continuous forest (Fig. 1). Within these sites, we established 33 plots of $3200 \mathrm{~m}^{2}(40 \mathrm{~m} \times 80 \mathrm{~m})$ distributed on flat land as follows: each 1 ha fragment had 1 plot; each 10 ha fragment had 3 plots; each 100 ha fragment had 4 plots and the continuous forest had 4 plots in each site. All plots were located $100 \mathrm{~m}$ apart. 


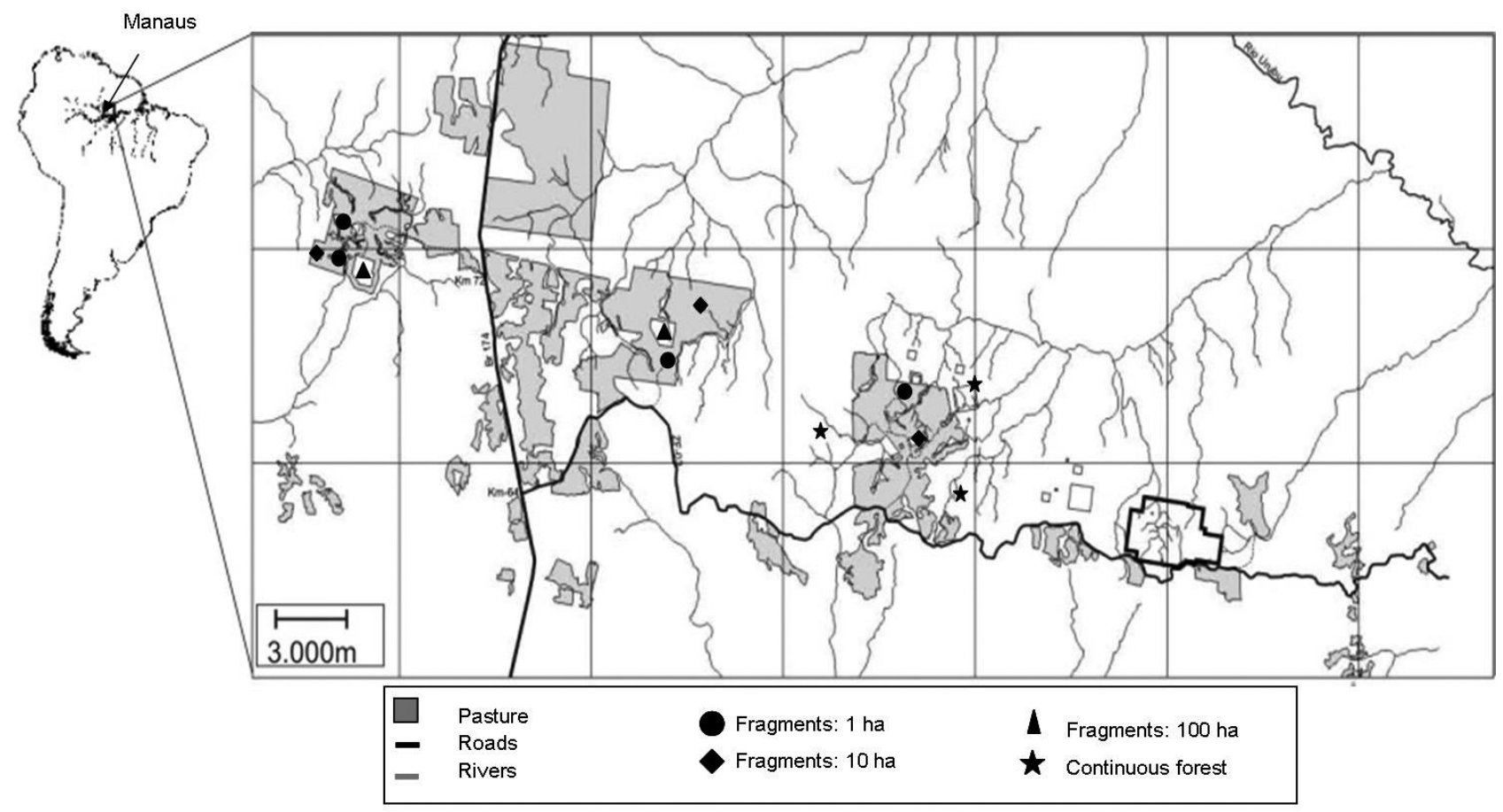

Figure 1. Spatial localization of the 12 localities sampled in the Central Amazon, Brazil. The study area of the Biological Dynamics of Forest Fragments Project (BDFFP).

To calculate vegetation cover, we located the 33 plots within a satellite image and classified the vegetation type as primary forest, secondary vegetation dominated by Cecropia sp. and Vismia sp., or pasture. The Geoprocessing laboratory of the BDFFP performed this classification based on a LANDSAT 7 image from 2001, using IDRISI software (Moreira, 2003). After locating the plots within the image, we calculated the proportion of primary forest and secondary vegetation in a buffer of $300 \mathrm{~m}$ surrounding the edge of each plot by means of digital analysis, using ArcView 3.2 (ESRI, 1996). Pasture was disregarded since its values were quite low (less than $5 \%$ ). We measured the vegetation cover in a buffer of $300 \mathrm{~m}$ because we expected that a change within this distance could influence habitat use by armadillos, since the typical movement range of resident adult armadillos has been reported to be less than $200 \mathrm{~m}$ (Loughry and McDonough, 1998; Loughry and McDonough, 2001). At each site $(n=12)$, the percentage cover of each vegetation type was estimated by calculating the mean of the percentages of the plots present.

Burrow censuses. Between February and August of 2003, we surveyed the 12 sites. Since temporal and spatial variation in habitat use is common in adult males (Loughry and McDonough, 1998), we surveyed the plots within each site twice to record the number and any change in the use of burrows. Censuses were completed within a time interval between of approximately 70 days. To survey each plot, we paced ten- $80 \mathrm{~m}$ transects, spaced 4 meters apart, and were thus able to detect all the burrows present. We recorded and flagged a burrow as 'active' when we observed footprints and the soil in the entrance or within the burrow had been disturbed. This use of indirect evidence to determine the status of a burrow is common in the study of armadillos due to the difficult nature of direct observation of these species, as reported in several studies (e.g., McDonough et al., 2000; Michalski and Peres, 2007). Burrow density was calculated per plot (number of burrows x $10000 \mathrm{~m}^{2}$ (1ha) / $3200 \mathrm{~m}^{2}$ (plot size)); an average was then taken of these estimates to give the density for each site. Burrow density was used as an independent variable in the statistical analysis rather than the number of burrows since the former enables direct comparisons between studies in other environments or even between taxa. The proportion of active burrows and the probability of occurrence of new burrows were also estimated as evidence of habitat use. The former was calculated as the number of active burrows in each site divided by the total number of recorded burrows in the same area. To calculate the probability of occurrence of a new burrow, the presence or absence of new burrows in the second census was transformed into a value of 1 or 0 . Statistical analysis. The proportion of primary forest cover was the measure of remnant habitat present, and was 
used as the independent variable in statistical analysis. To determine whether the proportion of active burrows varied between sites with different primary forest cover, we used an ANCOVA as a function of forest cover (continuous variable) and census (fixed), and the interaction forest cover $\mathrm{x}$ census. Furthermore, we performed independent linear regressions for the proportion of active burrows and the total density of burrows as a function of primary forest cover. To assess the probability of occurrence of new burrows, we performed a logistic regression where the dependent variable was the presence (1) or absence (0) of new burrows in the second census at each site, as a function of primary forest cover. Statistical analyses were conducted using JPM 5.01 software (SAS Cary, New Jersey, USA).

\section{Results}

Of 87 burrows recorded in the first census, 33 (38\%) were active. In the second census, 22 more burrows were detected and, of the total 109 burrows, 50 (46\%) showed signs of activity. Forty percent of the active burrows in the first census remained active in the second census. Burrow density varied between 2.78 and 14.80 burrows/ha, and no significant effect of primary forest cover was found for this variable. The proportion of active burrows was significantly affected by the percentage of primary forest cover $(F=46.654, p=0.0001)$, but was not affected by the census $(F=2.442, p=0.122)$, nor by the vegetation cover $\mathrm{x}$ census interaction $(F=0.231, p=0.631)$.

Sites with higher percentages of primary forest cover showed larger proportions of active burrows (first census $R^{2}=0.470, F=8.885, p=0.013$; second census $R^{2}=0.387$, $F=6.339, p=0.030$; Fig. 2), suggesting that these sites are used more intensely by armadillos. In contrast, no significant effect of primary forest cover was found on the probability of occurrence of new burrows $\left(X^{2}=1.24, p=\right.$ $0.2652)$.

\section{Discussion}

Spatial-temporal analysis of burrow excavation by animals can offer valuable information regarding the biology of a species (Kinlaw, 1999; Hayes et al., 2007; Arteaga and Venticinque, 2008; Cantú-Salzar et al., 2009). We found that the change in primary forest cover had an influence on some aspects of armadillo habitat use and may affect the spatial use dynamics of this group within a fragmented landscape. The proportion of active burrows was greater in areas with a higher percentage of primary forest cover. However, the probability of establishing new burrows was unaffected by this variable. Although armadillos dig new burrows in

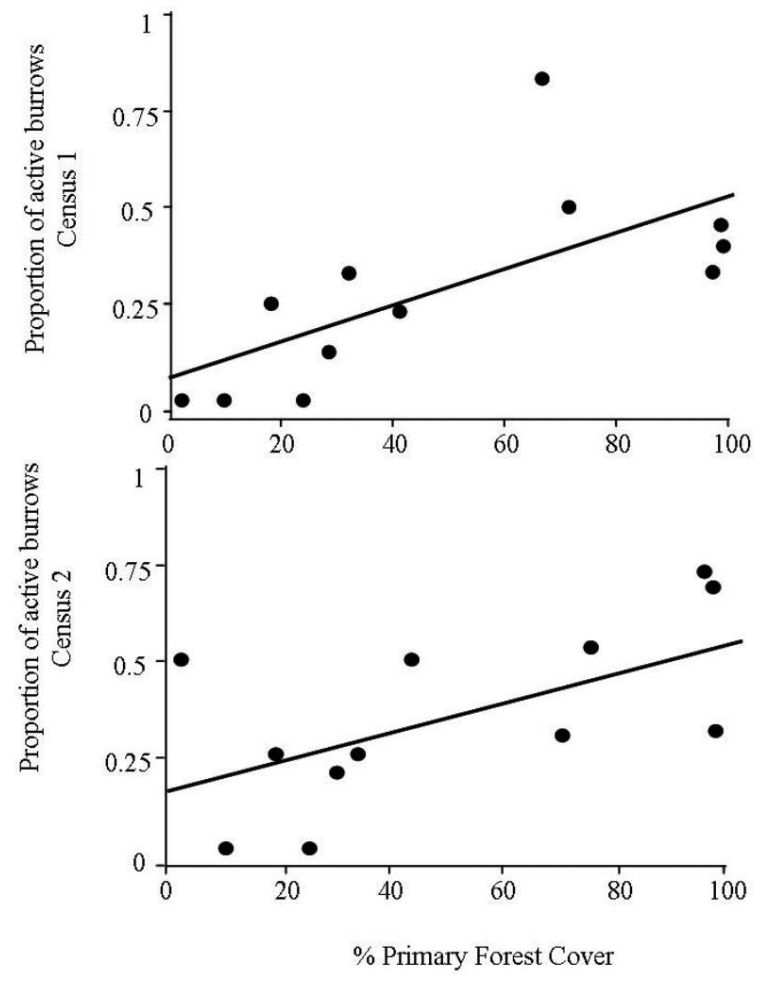

Figure 2. Relationship between primary forest cover and the proportion of active armadillo burrows in 2 different censuses (see detail in the text) in the Central Amazon, Brazil.

areas with different vegetation cover, sites featuring larger extensions of primary forest contained more active burrows, indicating a more intense habitat use, probably due to a greater permanence time of the individuals in the area.

Change in the primary forest cover can affect abiotic features that determine habitat selection. Microclimate conditions are modified throughout the different vegetation cover types. For example, areas with a higher percentage of primary vegetation cover may have lower temperatures and be less dry (Kapos et al, 1997; Pohlman et al., 2007; Pohlman et al., 2009; Laurance et al., 2011). These conditions probably affect the behavior of the armadillos as they are poor thermal regulators (McNab, 1980) and might prefer sites with more stable temperature and humidity conditions in order to maintain their metabolic rates. Thus, microclimatic conditions may influence the preference of armadillos for habitat areas with abundant primary forest cover. In addition, changes in the availability and amount of food can influence the presence and permanence time of several animal species within a geographic area (MacArthur and Pianka, 1966). For instance, the frequency of badger (Meles meles) burrows increases substantially in areas with a high abundance of food resources and moderate human disturbance (Virgós, 2002). As consumers of 
invertebrates (McBee and Baker, 1982), armadillos can be affected by modification of the available prey. Changes in insect community composition and abundance have been recorded in disturbed habitat (Vasconcelos, 1999; Narendra et al., 2011). Consequently, areas with a high percentage of primary forest may offer a relatively higher availability and diversity of invertebrates.

The presence of burrows in sites with different vegetation cover and the finding that changes in primary vegetation cover do not have an effect on burrow density, indicate that these animals are using different environments within the fragmented landscape. Previous study in this area has found that some armadillo species can use the matrix of surrounding forest patches (Timo, 2003), composed of secondary vegetation older than 30 years (Laurance et al., 2011). Furthermore, high burrow densities of the nine-banded armadillo ( $D$. novemcinctus) in medium size fragments ( $>200$ ha) and disturbed agrosystems have been found in 2 different regions in the Amazonian forest (Naughton-Treves et al., 2003; Michalski and Peres, 2007). Despite the fact that we recorded a $20 \%$ increase in the number of burrows between censuses, indicating once again that armadillos actively used the study area, the permanence time of individuals in patches seems to be influenced by the quantity and quality of the habitat surrounding their burrows. These animals have a great impact on the landscape as they actively modify the soil and their burrows serve as shelters for other species (McDonough and Loughry, 2007). However, the less intense habitat use detected in areas with a smaller percentage of primary vegetation cover would reduce this impact.

Our results suggest that habitat use by armadillo populations, as well as the ecological roles they play, will be diminished in areas that have a lower proportion of primary forest cover. Connectivity between patches, through corridors or regeneration within the matrix, may serve to mitigate the effect of deforestation on these species. Changes in habitat use patterns, abundance of mammal species, and their intra and interspecific interactions have been attributed to landscape fragmentation (Jorge, 2008; Jorge and Howe, 2009; Boyle and Smith, 2010; Melo et al., 2010). Such changes are increasing the extinction risk for various species and, as a consequence, may have an impact upon the dynamics of entire ecosystems.

\section{Acknowledgements}

We thank the Biological Dynamics of Forest Fragments Project (BDFFP) at the National Institute for Amazonian Research/Smithsonian Institution (INPA/SI) for the financing. We thank Rafael Bello, Braulio Santos, Camila González and William Magnusson for their valuable comments; and Keith Macmillan and Angélica Menchaca for improvements to the English version of the manuscript. This study represents the contribution number 581 in the technical series of the PDBFF.

\section{Literature cited}

Abba, A. M., S. F. Vizcaíno and M. H. Cassini. 2007. Effects of land use on the distribution of three species of armadillos in the Argentinean pampas. Journal of Mammalogy 88:502507.

Arteaga, M. C. and E. Venticinque. 2010. Cuevas de armadillos (Cingulata: Dasypodidae) en el Amazonas Central: son útiles para identificar especies? Edentata 11:29-33.

Arteaga, M. C. and E. Venticinque. 2008. Influence of topography on the location and density of armadillo burrows (Dasypodidae: Xenarthra) in the Central Amazon, Brazil. Mammalian Biology 73:262-266.

Barragán, F. C., E. Moreno, F. Escobar, G. Halffter and D. Navarrete. 2011. Negative impacts of human land use on dung beetle functional diversity. PLosOne 6:e17976.

Bierregaard, R. O. and P. C. Stouffer. 1997. Understory birds and the dynamic habitat mosaics in amazonian rainforests. In Tropical forest remnant: ecology, management and conservation of fragmented communities, W. F. Laurance and R.O. Bierregaard Jr. (eds.). University of Chicago Press, Chicago. p. 138-155.

Boyle, S. and A. T. Smith. 2010. Can landscape and species characteristics predict primate presence in forest fragments in the Brazilian Amazon? Biological Conservation 143:1134-1143.

Carter, T. S. and C. Encarnação. 1983. Characteristics and use of burrows by four species of armadillos in Brazil. Journal of Mammalogy 64:103-108.

Cantú-Salazar, L., M. G. Hidalgo-Mihart, C. A. López-González and A. González-Romero. 2009. Dry season den use by Pygmy Spotted Skunk (Spilogale pygmaea) in a tropical deciduous forest of Mexico. Biotropica 41:347-353.

Dharmarajan, G., J. C. Beasley, J. A. Fike and O. E. Rhodes Jr. 2009. Population genetic structure of raccoons (Procyon lotor) inhabiting a highly fragmented landscape. Canadian Journal of Zoology 87:814-824.

Eldridge, D. J. and W. G. Whitford. 2009. Badger (Taxidea taxus) disturbances increase soil heterogeneity in a degraded shrub-steppe ecosystem. Journal of Arid Environments 73:66-73.

Emmons, L. H. and F. Feer. 1997. Neotropical rainforest mammals: A field guide. Chicago: University of Chicago Press. 307 p.

Fahrig, L. 2003. Effects of habitat fragmentation on biodiversity. Annual Review of Ecology, Evolution and Systematics $34: 487-515$. 
Fearnside, P. M. 2003. A floresta Amazônica nas mudanças globais. Instituto Nacional de Pesquisas da Amazônia, Manaus. 134 p.

Gascon, C. and R. O. Bierregaard, Jr. 2001. The Biological Dynamics of Forest Fragments Project: the study site, experimental design and research activity. In Lessons from Amazonia: the ecology of a fragmented forest, R. O. Bierregaard Jr., C. Gascon, T. Lovejoy and R. Mesquita, R. (eds.). Yale University Press, New Haven. p. 31-46.

Gibbs, J. P. 2001. Demography versus habitat fragmentation as determinants of genetic variation in wild populations. Biological Conservation 100:15-20.

Hayes, L. D., A. S. Chesh and L. A. Ebensperger. 2007. Ecological predictors of range areas and use of burrow systems in the diurnal rodent, Octodon degus. Ethology 113:155-165.

Holland, G. J. and A. F. Bennett. 2007. Occurrence of small mammals in fragmented landscape: the role of vegetation heterogeneity. Wildlife Research 34:387-397.

Jorge, M. L. S. P. 2008. Effects of forest fragmentation on two sister genera of Amazonian rodents (Myoprocta acouchy and Dasyprocta leporine). Biological Conservation 141:617-623.

Jorge, M. L. S. P. and H. F. Howe. 2009. Can forest fragmentation disrupt a conditional mutualism? A case from central Amazon. Oikos 171:709-718.

Kapos, V., E. Wandelli, J. L. Camargo and G. Granade. 1997. Edge-related changes in environment and plants responses due to forest fragmentation in central Amazonia. In Tropical forest remnant: ecology, management and conservation of fragmented communities, W. F. Laurance and R. O. Bierregaard Jr. (eds.). University of Chicago Press, Chicago. p. 33-44.

Kinlaw, A. 1999. A review of burrowing by semi-fossorial vertebrates in arid environments. Journal of Arid Environmental 41:127-145.

Laurance, W. F., J. L. C. Camargo, R. C. C. Luizão, S. G. Laurance, S. L. Pimm, E. M. Bruna, P. C. Stouffer, G. B. Williamson, J. Benítez-Malvido, H. L. Vasconcelos, K. S. Van Houtan, C. E. Zartman, S. A. Boyle, R. K. Didham, A. Andrade and T. E. Lovejoy. 2011. The fate of Amazonian forest fragments: a 32-year investigation. Biological Conservation 144:56-67.

Laakkonen, J., R. N. Fisher and T. J. Case. 2001. Effect of land cover, habitat fragmentation and ant colonies on the distribution and abundance of shrews in southern California. Journal of Animal Ecology 70:776-788.

Loughry, W. J. and C. M. McDonough. 1998. Spatial patterns in a population of nine-banded armadillos (Dasypus novemcinctus). American Midland Naturalist 140:161-169.

Loughry, W. J. and C. M. McDonough. 2001. Natal recruitment and adult retention in a population of nine-banded armadillos. Acta Theriolica 46:393-406.

MacArthur, R. H. and E. R. Pianka. 1966. On optimal use of a patchy environment. American Naturalist 100:603-609.

Machicote, M., L. C. Branch and D. Villarreal. 2004. Burrowing owls and burrowing mammals: are ecosystem engineers interchangeable as facilitators? Oikos 106:527-535.

Malcolm, J. R. 1997. Biomass and diversity of small mammals in Amazonian forest fragments. In Tropical forest remnants: ecology, management and conservation of fragmented communities, W. F. Laurance and R. O. Bierregaard Jr. (eds.). University of Chicago Press, Chicago. p. 207-221.

McBee, K. and R. J. Baker. 1982. Dasypus novemcinctus. Mammalian Species 162:1-9.

McDonough, C. M., M. A. Delaney, P. Quoc, M. S. Blackmore and W. J. Loughry. 2000. Burrow characteristics and habitat associations of armadillos in Brazil and the United States of American. Revista de Biología Tropical 48:109-120.

McDonough, C. M. and W. J. Loughry. 2008. Behavioral ecology of armadillos. In The Biology of the Xenartha, S. F. Vizcaíno, and W. J. Loughry (eds.). University Press of Florida, Gainesville. p. 281-293.

McNab, B. K. 1980. Energetics and the limits to a temperate distribution in armadillos. Journal of Mammalogy 61:606627.

Melo, F. P. L., E. Martínez-Salas, J. Benítez-Malvido and G. Ceballos. 2010. Forest fragmentation reduces recruitment of large-seeded tree species in a semi-deciduous tropical forest of southern Mexico. Journal of Tropical Ecology 26:35- 43.

Michalski, F. and C. A. Peres. 2007. Disturbance-mediated mammal persistence and abundance-area relationships in Amazonian forest fragments. Conservation Biology 21:1626-1640.

Moreira, M. 2003. Uso de sensoramento remoto para avaliar a dinâmica de sucessão secundária na Amazonia Central. Tesis, Instituto Nacional de Pesquisas da Amazônia, Brazil. 103 p.

Narendra, A., H. Gibb and T. M. Musthak. 2011. Structure of ant assemblages in Western Ghats, India: role of habitat, disturbance and introduced species. Insect Conservation and Diversity 4:132-141.

Naughton-Treves, L., J. L. Mena, A. Treves, N. Alvarez and V. C. Radeloff. 2003. Wildlife survival beyond park boundaries: the impact of slash-and-burn agriculture and hunting on mammals in Tambopata, Peru. Conservation Biology 17:1106-1117.

O’Dea, N. and R. J. Whittaker. 2007. How resilient are Andean montane forest bird communities to habitat degradation? Biodiversity and Conservation 16:1131-1159.

Oliveira, A. and S. Mori. 1999. A central Amazonian terra firme forest: high tree species richness on poor soils. Biodiversity and Conservation 8:1219-1244.

Pires, J. M. and G. T. Prance. 1985. The vegetation type of 
Brazilian Amazon. In Key environment: Amazonia, G. T. Prance and T. Lovejoy (eds.). Pergamon Press, Oxford. p. 109-145.

Pohlman, C. L., S. M. Turton and M. Goosem. 2009. Temporal variation in microclimatic edgeeffects near powerlines, highways and streams in Australian tropical rainforest. Agricultural and Forest Meteorology 149:84-95.

Pohlman, C. L. , S. M. Turton and M. Goosem. 2007. Edge effects of linear canopy openings in tropical rain forest understory microclimate. Biotropica 39:62-71.

Stouffer, P. C. and R. O. Bierregaard Jr. 1995. Effects of forest fragmentation on understory hummingbirds in Amazônia, Brasil. Conservation Biology 9:1086-1095.

Timo, T. P. 2003. Influência da fragmentação e matriz sobre a comunidade de mamíferos de médio e grande porte em uma floresta de terra firme da Amazônia Central. Tesis, Instituto Nacional de Pesquisas da Amazônia, Brazil. 46 p.

Vasconcelos, H. L. 1999. Effects of forest disturbance on the structure of ground-foraging ant communities in central Amazonia. Biodiversity and Conservation 8:409-420.

Virgós, E. 2002. Are habitat generalists affected by forest fragmentation? A test with Eurasian badgers (Meles meles) in coarse-grained fragmented landscape of central Spain. Journal of Zoology 258: 313-318.

Wesche, K., K. Nadrowski and V. Retzer. 2007. Habitat engineering under dry conditions: the impact of pikas (Ochotona pallasi) on southern Mongolian mountain steppes. Journal of Vegetation Science 18:665-674. 